\title{
PENGARUH PENGGUNAAN MODEL PEMBELAJARAN QUANTUM TEACHING BERBANTUAN MEDIA AUDIOVISUAL TERHADAP MOTIV ASI DAN HASIL BELAJAR DASAR-DASAR AKUNTANSI SISWA KELAS X AK DI SMK N 1 SINGARAJA TAHUN AJARAN 2017/2018
}

\author{
Ni Made Maha Wardani ${ }^{1}$, Iyus Akhmad Haris ${ }^{2}$, Lulup Endah Tripalupi ${ }^{3}$ \\ Jurusan Pendidikan Ekonomi \\ Universitas Pendidikan Ganesha \\ Singaraja, Indonesia \\ e-mail: mahawardani83@gmail.com¹, iyus.haris@gmail.com², \\ lulup tripalupi@yahoo.com ${ }^{3}$
}

\begin{abstract}
Abstrak
Penelitian ini bertujuan untuk mengetahui perbedaan motivasi dan hasil belajar, perbedaan motivasi belajar, perbedaan hasil belajar dasar-dasar akuntansi pada siswa kelas X AK di SMK N 1 Singaraja. Jenis penelitian ini adalah eksperimen semu, dengan desain Non Equivalen post test only control group desain. Data hasil belajar dasar-dasar akuntansi dikumpulkan dengan tes dan data motivasi belajar dengan kuesioner. Metode analisis yang digunakan dalam penelitian ini adalah analisis inferensial dan menggunakan uji Manova. Hasil penelitian menunjukkan bahwa terdapat perbedaan motivasi dan hasil belajar dasar-dasar akuntansi antara kelompok siswa yang belajar dengan model pembelajaran quantum teaching berbantuan media audiovisual dan kelompok siswa yang belajar tidak dengan model pembelajaran quantum teaching berbantuan media audiovisual ditunjukkan dari nilai sig $<0,05(0,000<0,05)$, terdapat perbedaan motivasi belajar dasar-dasar akuntansi antara kelompok siswa yang belajar dengan model pembelajaran quantum teaching berbantuan media audiovisual dan kelompok siswa yang belajar tidak dengan model pembelajaran quantum teaching berbantuan media audiovisual ditunjukkan dari nilai sig < $0,05(0,013<0,05)$, terdapat perbedaan hasil belajar dasar-dasar akuntansi antara kelompok siswa yang belajar dengan model pembelajaran quantum teaching berbantuan media audiovisual dan kelompok siswa yang belajar tidak dengan model pembelajaran quantum teaching berbantuan media audiovisual ditunjukkan dari nilai sig $<0,05(0.000<0,05)$.
\end{abstract}

Kata kunci : quantum teaching, media audiovisual, motivasi belajar, hasil belajar.

\begin{abstract}
This study aimed at investigating the differences of student's motivation and learning outcomes, the differences of student's motivation, the differences of learning outcomes of accounting basics at tenth grade students of Accounting Department in SMK N 1 Singaraja. This study was quasi experiment with Non Equivalent post test only control group design. Data of learning outcomes of Accounting Basics was collected by using test and the data of learning motivation was collected by using questionnaire. Method of data analysis used in this study was an inferential analysis and Manova test. The result of the study showed that there was a difference in motivation and learning outcome of Accounting Basics between students who were learn by using quantum teaching model assisted audiovisual media and students who were not learn by using quantum teaching model assisted audiovisual media and it was shown from sig $<0,05$ $(0,000<0,05)$, there was a difference in learning motivation of Accounting Basics between students who were learn by using quantum teaching model assisted by audiovisual media and students who were not learn by using quantum teaching model assisted by audiovisual media and it was shown from sig $<0,05(0,013<0,05)$, there was a difference in learning result of Accounting Basics between students who were learn by using quantum teaching model assisted by audiovisual media and students who were not learn by using quantum teaching model assisted by audiovisual media and it was shown from the sig $<0,05(0,000<0,05)$
\end{abstract}

Keywords : quantum teaching, audiovisual media, learning motivation, learning outcomes 


\section{PENDAHULUAN}

Perkembangan pendidikan di Indonesia dewasa ini berubah dengan cepat, sejalan dengan laju teknologi dan ilmu pengetahuan. Perkembangan pendidikan yang cukup pesat ini juga ditopang oleh usaha pemerintah, dalam hal ini Kementrian Pendidikan dan Kebudayaan yang senantiasa melakukan pembenahan sistem pendidikan. Dengan harapan agar dapat dicapi hasil tamatan yang cukup baik, tidak hanya dalam segi kuantitas tetapi juga kualitas, termasuk pembenahan sistem pendidikan di Sekolah Menengah Kejuruan (SMK).

Sekolah Menengah Kejuruan merupakan salah satu lembaga pendidikan formal yang menyiapkan anak didik menjadi tenaga kerja tingkat yang profesional sesuai dengan keahliannya. Untuk mencapai tujuan tersebut, pendidikan kejuruan dalam hal ini Kementrian Pendidikan dan Kebudayaan berusaha memperbaiki unsur-unsur pendidikan yang meliputi sarana kurikulum, kualitas guru dan proses pengajaran yang dilaksanakan di SMK.

Dalam memperbaiki kualitas proses pembelajaran, guru memiliki peran yang sangat penting dalam proses pembelajaran di dalam kelas. Seorang guru dituntut harus memiliki kompetensi dalam merancang suatu kegiatan pembelajaran yang menyenangkan sehingga dapat menciptakan kondisi belajar yang aktif, tidak monoton dan dapat menumbuhkan semangat belajar serta partisipasi dalam proses pembelajaran di dalam kelas. Pembelajaran yang menyenangkan, kreatif, dan inovatif, serta pendidikan berkarakter merupakan salah satu misi dari pembelajaran dalam kurikulum 2013. Pemilihan model pembelajaran yang tepat akan berpengaruh terhadap pencapaian tujuan pembelajaran dengan mempertimbangkan situasi dan kondisi yang dimiliki oleh peserta didik.

SMK Negeri 1 Singaraja adalah sekolah yang sudah menggunakan kurikulum 2013. Kurikulum 2013 merupakan kurikulum yang mengutamakan pada pemahaman, skill, dan pendidikan berkarakter, dimana peserta didik dituntut untuk paham atas materi, aktif dalam proses berdiskusi, imajinatif, dan presentasi serta memiliki sopan santun dalam bersikap dan mempunyai disiplin yang tinggi.

Dasar-dasar akuntansi merupakan salah satu mata pelajaran produktif akuntansi, mata pelajaran ini diberikan pada semester 1 dan 2 kelas $X$ program akuntansi. Selain itu, mata pelajaran dasardasar akuntansi memegang peranan penting dalam kehidupan sehari-hari, sebab dasar-dasar akuntansi melatih siswa berfikir logis, kritis, dan kreatif. Pembelajaran produktif akuntansi juga merupakan pembelajaran yang saling berkaitan antara materi yang satu dengan materi yang lainnya yang merupakan suatu siklus yang tidak bisa diajarkan secara terpisah karena pelajaran ini merupakan dasar sebelum menempuh mata pelajaran akuntansi yang lebih kompleks. Begitu pentingnya mata pelajaran akuntansi karena mengantarkan siswa pada pemahaman awal konsep akuntansi dan bertujuan agar siswa memiliki kemampuan teknis pencatatan sehingga dapat menjadi teknisi akuntansi yang terampil, sesuai dengan tuntutan kurikulum. Oleh karena pentingnya pelajaran dasar-dasar akuntansi di SMK khususnya jurusan Akuntansi, maka sangat diperlukan pembelajaran yang sesuai dengan materi yang ada, sehingga memudahkan siswa dalam belajar dasardasar akuntansi.

Kenyataannya di SMK Negeri 1 Singaraja, pembelajaran dasar-dasar akuntansi saat ini masih belum sesuai harapan. Hal tersebut dikarenakan masih banyak kendala yang dihadapi siswa dan guru dalam proses pembelajaran dasardasar akuntansi. Siswa di SMK Negeri 1 Singaraja mengalami kesulitan dalam memahami pelajaran dasar-dasar akuntansi yang dianggap sukar sehingga berdampak pada hasil belajar yang mereka peroleh. Selain hal tersebut, guru juga menyatakan bahwa dalam pembelajaran dasar-dasar akuntansi guru lebih sering mengajar dengan metode ceramah dan tanya jawab. Proses pembelajaran ini membuat siswa bosan, sehingga walaupun secara fisik siswa ada di dalam kelas, namun secara mental siswa sekali tidak mengikuti jalannya proses pembelajaran. Hal ini menyebabkan pikiran siswa tidak 
konsentrasi bahkan bisa menyebabkan siswa mengantuk.

$\mathrm{Hal}$ tersebut diperkuat kembali berdasarkan hasil observasi yang peneliti lakukan, terlihat bahwa dalam proses pembelajaran siswa terlihat kurang aktif dalam mengikuti pembelajaran. Pada saat guru memberikan kesempatan kepada siswa untuk bertanya mengenai materi yang dibahas, tidak ada siswa yang bertanya. Ketika diberikan kesempatan untuk menjawab dan memberikan pendapat mengenai materi pelajaran yang sudah dijelaskan hanya ada 2 (dua) hingga 4 (empat) siswa yang angkat tangan untuk menjawab dan memberikan pendapatnya.

Kondisi itu melahirkan anggapan bahwa dasar-dasar akuntansi itu merupakan mata pelajaran yang kurang menarik, membosankan dan membuat siswa cendrung pasif, hanya mencatat, dan mendengarkan sesuai perintah guru tanpa berupaya untuk mengalami sendiri dalam memahami konsep-konsep yang dipelajari. Dengan demikian, pembelajaran menjadi kurang meriah, kurang menyenangkan, dan hanya berpusat pada guru. Sehingga berdampak pada motivasi dan hasil belajar siswa yang rendah terutama hasil belajar ranah kognitif pada mata pelajaran dasardasar akuntansi. Uno (2008:23) menyatakan, "motivasi belajar adalah dorongan internal dan eksternal pada siswa-siswa yang sedang belajar untuk mengadakan perubahan tingkah laku". Pendapat tersebut sejalan dengan pendapat Sardiman (2005:73) yang menyatakan, motivasi belajar adalah perubahan keseluruhan kegiatan belajar untuk mencapai tujuan yang dikehendaki".

$$
\text { Berdasarkan hasil pencatatan }
$$
dokumen yang dilakukan pada tanggal 27 Juli 2017, diperoleh data rata-rata nilai ulangan harian mata pelajaran dasar-dasar akuntansi siswa kelas X Akuntansi di SMK $N 1$ Singaraja, yaitu kelas $X$ Akuntansi $A$ dengan rata-rata nilai 63,24 kelas $X$ Akuntansi $B$ dengan rata-rata nilai 65,80 , kelas $X$ Akuntansi $C$ dengan rata-rata nilai 66,03 dan kelas $X$ Akuntansi $D$ dengan rata-rata nilai 65,00 semua nilai mata pelajaran dasar-dasar akuntansi di kelas $X$ Akuntansi masih di bawah KKM, yaitu di bawah 75,00 (Dokumen Guru mata pelajaran Dasar-Dasar Akuntansi Kelas $\mathrm{X}$ AK di SMK N 1 Singaraja, 2017).

Rendahnya motivasi dan hasil belajar siswa pada mata pelajaran dasardasar akuntansi tersebut perlu dicarikan suatu solusi. Dalam hal ini diperlukan perubahan pradigma guru dalam pembelajaran, dalam artian merubah cara mengajar guru dari yang masih menggunakan pembelajaran konvensional menjadi pembelajaran yang lebih inovatif, diharapkan dapat menarik minat siswa untuk mempelajari pelajaran dasar-dasar akuntansi dan dapat mendorong siswa untuk lebih berperan aktif dalam belajar, sehingga berdampak pada hasil belajar yang dicapai siswa. Menurut Rusman (2015:67), "hasil belajar adalah pengalaman yang diperoleh siswa dalam tiga ranah (domain), yaitu ranah kognitif, afektif, dan psikomotor". Sedangkan menurut Ruseffendi (dalam Susanto, 2013) menyatakan, faktor-faktor yang mempengaruhi hasil belajar meliputi kecerdasan, kesiapan anak, bakat anak, kemauan belajar, minat anak, model penyajian materi, pribadi dan sikap guru, suasana belajar, kompetensi guru, dan kondisi masyarakat.

Untuk itu perlu adanya variasi penggunaan model pembelajaran untuk meningkatkan motivasi dan hasil belajar dasar-dasar akuntansi siswa. "Model pembelajaran merupakan gambaran upaya guru untuk membuat situasi dalam kegiatan pembelajaran sehingga mendorong siswa untuk belajar" (Sobandi, 2008:172). Sedangkan menurut Santayasa (dalam Trianto, 2007:48), "model pembelajaran merupakan kerangka konseptual yang melukiskan prosedur yang sistematis dalam mengorganisasikan pengalaman belajar untuk mencapai tujuan belajar". Salah satu model pembelajaran yang dapat digunakan adalah model pembelajaran Quantum Teaching. Deporter, dkk (2010:3-10) menyatakan "Quantum Teaching adalah pengubahan belajar yang meriah dengan segala nuansanya". Model tersebut menguraikan cara-cara baru yang memudahkan proses belajar lewat pemaduan unsur seni dan pencapaian- 
pencapain yang terarah. Model pembelajaran quantum teaching memiliki kerangka rancangan belajar, yaitu TANDUR (Tumbuhkan, Alami, Namai (pemberian nama), Demonstrasikan, Ulangi dan Rayakan), tumbuhkan minat dengan memuaskan "apakah manfaatnya bagiku" (AMBAK), dan memanfaatkan kehidupan pelajar.

\section{Dengan kerangka TANDUR}

keaktifan siswa akan lebih ditingkatkan, membuat pelajaran lebih menyenangkan dan meriah. Kemeriahan yang dimaksud akan tercipta dengan keterlibatan aktif seluruh siswa dalam pembelajaran. Menurut Usman (dalam Suwatra, dkk, 2015), keterlibatan aktif seluruh siswa akan menjadikan pembelajaran efektif dan siswa dapat mencapai hasil belajar yang diinginkan.

Kemeriahan ini bisa dimaksimalkan dengan berbantuan media. Djamarah \& Aswan (2016:121) menyatakan, "media adalah alat bantu apa saja yang dapat dijadikan sebagai penyalur pesan guna mencapai tujuan pengajaran" .Sedangkan menurut Sadiman, dkk (2006), media adalah segala sesuatu yang dapat digunakan untuk menyalurkan pesan dari pengirim ke penerima sehingga dapat merangsang pikiran, perasaan, dan minat serta perhatian siswa sedemikian rupa sehingga proses belajar terjadi.

Salah satunya adalah media audiovisual. Arsyad (2013:73) menyatakan, "media audiovisual merupakan media yang menampilkan unsur gambar dan suara secara bersamaan". Kemampuan media ini dianggap lebih baik dan lebih menarik dan bisa memberikan pengalaman langsung ke siswa. Media audiovisual digunakan pada tahap "Alami dan Namai" dalam rancangan model quantum teaching. Penggunaan media audiovisual dapat menambah motivasi belajar siswa sehingga perhatian siswa terhadap materi pembelajaran dapat lebih meningkat (Sanjaya, 2008). Hal ini dapat membantu siswa untuk lebih mudah mencapai hasil belajar yang diinginkan.

Berdasarkan uraian di atas, maka kajian ini memiliki tujuan secara umum untuk mengetahui perbedaan motivasi dan hasil belajar dasar-dasar akuntansi pada siswa kelas $X$ Akuntansi di SMK N 1
Singaraja tahun ajaran 2017/2018. Secara lebih rinci, tujuan penelitian ini untuk mengetahui, perbedaan motivasi dan hasil belajar dasar-dasar akuntansi antara kelompok siswa yang belajar dengan menggunakan model pembelajaran quantum teaching berbantuan media audiovisual dan kelompok siswa yang belajar tidak dengan menggunakan model pembelajaran quantum teaching berbantuan media audiovisual pada siswa kelas $X$ Akuntansi di SMK N 1 Singaraja tahun ajaran 2017/2018, perbedaan motivasi belajar dasar-dasar akuntansi antara kelompok siswa yang belajar dengan menggunakan model pembelajaran quantum teaching berbantuan media audiovisual dan kelompok siswa yang belajar tidak dengan menggunakan model pembelajaran quantum teaching berbantuan media audiovisual pada siswa kelas $X$ Akuntasnsi di SMK N 1 Singaraja tahun ajaran 2017/2018, perbedaan hasil belajar dasar-dasar akuntansi antara kelompok siswa yang belajar dengan menggunakan model pembelajaran quantum teaching berbantuan media audiovisual dan kelompok siswa yang belajar tidak dengan menggunakan model pembelajaran quantum teaching berbantuan media audiovisual pada siswa kelas X Akuntansi di SMK N 1 Singaraja tahun ajaran 2017/2018.

\section{METODE}

Penelitian ini termasuk penelitian eksperimen semu karena tidak semua variabel yang relevan dikontrol atau dimanipulasi, kecuali beberapa variabel yang diteliti. Rancangan penelitian yang digunakan adalah Non-Equivalent Post-tes Only Control Group Design. Subjek dalam penelitian ini adalah siswa kelas X AK B sebagai kelas eksperimen yang berjumlah 34 orang yang terdiri dari 26 orang perempuan dan 8 orang laki-laki dan kelas $X$ AK $C$ sebagai kelas kontrol yang berjumlah 34 orang yang terdiri dari 26 orang perempuan dan 8 orang laki-laki. Adapun objek penelitian ini, adalah motivasi belajar dasar-dasar akuntansi, hasil belajar dasar-dasar akuntansi dan model pembelajaran quantum teaching berbantuan media audiovisual. 
Dalam penelitian ini peneliti menggunakan jenis data kuantitatif yang datanya didapatkan dari kuesioner dan tes yang diberikan kepada siswa. Sumber data yang digunakan adalah data primer yaitu "data yang diperoleh dari sumber pertama atau diperoleh secara langsung dari sumber pertama" (Agung, 2014:90), yaitu dari siswa kelas X Akuntansi di SMK N 1 Singaraja.

Metode yang digunakan untuk mengumpulkan data motivasi belajar dasardasar akuntansi adalah metode kuesioner. Kuesioner merupakan cara memperoleh atau mengupulkan data dengan memberikan suatu daftar pertanyaan kepada siswa. Jenis kuesioner yang digunakan adalah kuesioner tertutup yaitu kuesioner yang sudah disediakan jawabannya sehingga siswa tinggal memilih dan menjawab langsung. Kuesioner diukur dengan menggunakan skala pengukuran yang disebut dengan skala likert dengan rentang sekor 1-5, yaitu sangat setuju dengan skor 5 , setuju dengan skor 4 , raguragu dengan skor 3 , tidak setuju dengan skor 2, dan sangat tidak setuju dengan skor 1 (Koyan, 2011). Sedangkan metode tes digunakan untuk mengumpulkan data hasil belajar kognitif dalam pelajaran dasar-dasar akuntansi. Tes hasil belajar dibuat dalam bentuk pilihan ganda yang diberikan pada saat post-test. Jawaban yang benar mendapat skor 100 (seratus) dan jawaban yang salah mendapat skor 0 (nol).

Sebelum instrumen diberikan kesiswa, terlebih dahulu harus dilakukan uji validitas dan reliabilitas untuk mengetahui layak atau tidaknya pertanyaan tersebut digunakan untuk mengambil data. Koyan (2011:124) menyatakan, "uji validitas adalah ketepatan alat ukur dengan hal yang diukur". Uji reliabilitas adalah keterandalan alat ukur atau keajegan alat ukur (Koyan, 2011). Data dikatakan valid jika signifikansinya $<5 \%$ dan data dikatakan reliabel jika Alpha $>0,70$.

Untuk uji validitas kuesioner menggunakan uji validitas butir sedangkan untuk uji tes digunakan uji validitas isi dengan menggunakan formula Gregory (dalam Candiasa, 2011), selanjutnya uji reliabilitas digunakan untuk menguji kuesioner untuk mengetahui data tersebut reliabel atau tidak. Untuk menganalisis data yang diperoleh digunakan teknik analisis inferensial parametrik. Analisis inferensial digunakan untuk menguji suatu hipotesis penelitian yang diajukan peneliti. Pengujian hipotesis yang digunakan dalam penelitian ini adalah uji Manova. Uji Manova digunakan untuk menyelidiki pengaruh satu variabel independen terhadap dua variabel dependen dan untuk menyelidiki pengaruh satu variabel independen terhadap satu variabel dependen.

Sebelum dilakukan pengujian hipotesis untuk mendapatkan simpulan, maka prasyarat yang harus dipenuhi adalah melakukan uji asumsi, yaitu uji normalitas sebaran data, homogenitas varian, dan homogenitas matrik. Uji normalitas data digunakan untuk mengetahui data tesebut berdistribusi normal atau tidak. Data dikatakan berdistribusi normal apabila signifikansi yang peroleh $>0.05$. Uji homogenitas varian digunakan untuk memperoleh data empiris bahwa perbedaan yang terjadi pada uji hipotesis benar-benar terjadi akibat adanya perbedaan antara kelompok. Data dikatakan homogen apabila signifikansi yang diperoleh $>0,05$. Uji homogenitas matriks varian/covarian digunakan untuk mengetahui kelompok- kelompok data yang dibandingkan memiliki varian yang homogen. Data dikatakan memiliki varian yang homegen apabila signifikansi yang diperoleh $>0,05$. Jika semua syarat tersebut dipenuhi maka uji Manova dapat dilakukan. Untuk analisis ini dilakukan dengan menggunakan bantuan SPSS 17.0 for windows.

\section{HASIL DAN PEMBAHASAN Hasil Penelitian}

Hasil analisis yang menunjukkan terdapat perbedaan motivasi dan hasil belajar dasar-dasar akuntansi antara kelompok siswa yang belajar dengan menggunakan model pembelajaran quantum teaching berbantuan media audiovisual dan kelompok siswa yang belajar tidak dengan menggunakan model pembelajaran quantum teaching berbantuan media audiovisual pada siswa kelas X Akuntansi. Hasil output SPSS 17.0 for windows dapat dilihat pada tabel 1. 
Tabel 1. Hasil Uji Manova Variabel Independen Terhadap 2 Variabel Dependen Multivariate Tests ${ }^{\mathrm{b}}$

\begin{tabular}{|c|c|c|c|c|c|c|}
\hline \multirow{2}{*}{$\frac{\text { Effect }}{\text { Intercept }}$} & & Value & \multirow{2}{*}{$\begin{array}{c}F \\
2609.581^{a} \\
2609581^{a}\end{array}$} & Hypothesis df & Error df & Sig. \\
\hline & $\begin{array}{l}\text { Pillai's Trace } \\
\text { Wilks' Lambda }\end{array}$ & $\begin{array}{l}.988 \\
.012\end{array}$ & & $\begin{array}{l}2.000 \\
2.000\end{array}$ & $\begin{array}{l}65.000 \\
65.000\end{array}$ & $\begin{array}{l}.000 \\
.000\end{array}$ \\
\hline & Hotelling's Trace & 80.295 & $2609.581^{a}$ & 2.000 & 65.000 & .000 \\
\hline & Roy's Largest Root & 80.295 & $2609.581^{a}$ & 2.000 & 65.000 & .000 \\
\hline \multirow[t]{3}{*}{ Kelas } & $\begin{array}{l}\text { Pillai's Trace } \\
\text { Wilks' Lambda }\end{array}$ & $\begin{array}{l}.319 \\
.681\end{array}$ & $\begin{array}{l}15.241^{\mathrm{a}} \\
15.241^{\mathrm{a}}\end{array}$ & $\begin{array}{l}2.000 \\
2.000\end{array}$ & $\begin{array}{l}65.000 \\
65.000\end{array}$ & $\begin{array}{l}.000 \\
.000\end{array}$ \\
\hline & Hotelling's Trace & 469 & $15.241^{\mathrm{a}}$ & 2.000 & 65.000 & .000 \\
\hline & Roy's Largest Root & .469 & $15.241^{\mathrm{a}}$ & 2.000 & 65.000 & .000 \\
\hline
\end{tabular}

a. Exact statistic

b. Design: Intercept + Kelas

Hasil pengolahan data menunjukkan bahwa harga F untuk Pillai's Trace, Wilk's Lambda, Hotteling's Trace, Ray's Largest Root memiliki $F_{\text {hitung }} 15,241$ dan memiliki signifikansi sebesar $0,000<0,05$. Hal ini berarti F untuk Pillai's Trace, Wilk's Lambda, Hotteling's Trace, Ray's Largest Root semuanya signifikan.

Jadi terdapat perbedaan motivasi dan hasil belajar dasar-dasar akuntansi antara kelompok siswa yang belajar dengan menggunakan model pembelajaran quantum teaching berbantuan media audiovisual dan kelompok siswa yang belajar tidak dengan menggunakan model pembelajaran quantum teaching berbantuan media audiovisual pada siswa kelas X Akuntansi.

Hasil analisis yang menunjukkan terdapat perbedaan motivasi belajar dasardasar akuntansi antara kelompok siswa yang belajar dengan menggunakan model pembelajaran quantum teaching berbantuan media audiovisual dan kelompok siswa yang belajar tidak dengan menggunakan model pembelajaran quantum teaching berbantuan media audiovisual pada siswa kelas X Akuntansi. Hasil output SPSS 17.0 for windows dilihat pada tabel

Tabel 2. Hasil Uji Manova Variabel Independen Terhadap 1 Variabel Dependen Tests of Between-Subjects Effects

\begin{tabular}{|c|c|c|c|c|c|c|}
\hline Source & $\begin{array}{l}\text { Dependent } \\
\text { Variable }\end{array}$ & $\begin{array}{l}\text { Type III Sum of } \\
\text { Squares }\end{array}$ & $\mathrm{df}$ & Mean Square & $\mathrm{F}$ & Sig. \\
\hline \multirow[t]{2}{*}{ Corrected Model } & Motivasi_Belajar & $1134.204^{\mathrm{a}}$ & 1 & 1134.204 & 6.552 & .013 \\
\hline & Hasil_Bēajar & $3559.765^{b}$ & 1 & 3559.765 & 24.099 & .000 \\
\hline \multirow[t]{2}{*}{ Intercept } & Motivasi_Belajar & 452670.617 & 1 & 452670.617 & 2614.845 & .000 \\
\hline & Hasil_Belajar & 387315.059 & 1 & 387315.059 & 2622.046 & .000 \\
\hline \multirow[t]{2}{*}{ Kelas } & Motivasi_Belajar & 1134.204 & 1 & 1134.204 & 6.552 & .013 \\
\hline & Hasil_Belajar & 3559.765 & 1 & 3559.765 & 24.099 & .000 \\
\hline \multirow[t]{2}{*}{ Error } & Motivasi_Belajar & 11425.632 & 66 & 173.116 & & \\
\hline & Hasil_Belajar & 9749.176 & 66 & 147.715 & & \\
\hline \multirow[t]{2}{*}{ Total } & Motivasi_Belajar & 465230.453 & 68 & & & \\
\hline & Hasil_Belajar & 400624.000 & 68 & & & \\
\hline \multirow[t]{2}{*}{ Corrected Total } & Motivasi_Belajar & 12559.836 & 67 & & & \\
\hline & Hasil_Belajar & 13308.941 & 67 & & & \\
\hline
\end{tabular}

a. $R$ Squared $=, 090$ (Adjusted R Squared $=, 077$ )

b. R Squared $=, 267$ (Adjusted R Squared $=, 256$ ) 
Berdasarkan Tabel 2 di atas tampak bahwa nilai $F_{\text {hitung }}$ adalah 6,552 dan memiliki nilai signifikansi sebesar 0,013<0,05. Dengan demikian, hipotesis $\mathrm{H}_{0}$ ditolak. Hal ini berarti terdapat perbedaan motivasi belajar dasar-dasar akuntansi antara kelompok siswa yang belajar dengan menggunakan model pembelajaran quantum teaching berbantuan media audiovisual dan kelompok siswa yang belajar tidak dengan menggunakan model pembelajaran quantum teaching berbantuan media audiovisual pada siswa kelas X Akuntansi.

Hasil analisis yang menunjukkan terdapat perbedaan hasil belajar dasardasar akuntansi antara kelompok siswa yang belajar dengan menggunakan model pembelajaran quantum teaching berbantuan media audiovisual dan kelompok siswa yang belajar tidak dengan menggunakan model pembelajaran quantum teaching berbantuan media audiovisual pada siswa kelas X Akuntansi

Berdasarkan tabel 2 di atas tampak bahwa nilai $F_{\text {hitung }}$ adalah 24,099 dan nilai signifikansi sebesar $0,000<0,05$. Dengan demikian, hipotesis $\mathrm{H}_{0}$ ditolak. Hal ini berarti bahwa terdapat perbedaan hasil belajar dasar-dasar akuntansi antara kelompok siswa yang belajar dengan menggunakan model pembelajaran quantum teaching berbantuan media audiovisual dan kelompok siswa yang belajar tidak dengan menggunakan model pembelajaran quantum teaching berbantuan media audiovisual pada siswa kelas X Akuntansi

\section{Pembahasan}

Berdasarkan hasil penelitian yang diperoleh dapat dibuktikan bahwa terdapat perbedaan motivasi dan hasil belajar dasardasar akuntansi antara kelompok siswa yang belajar dengan menggunakan model pembelajaran quantum teaching berbantuan media audiovisual dan kelompok siswa yang belajar tidak dengan menggunakan model pembelajaran quantum teaching berbantuan media audiovisual, terdapat perbedaan motivasi belajar dasar-dasar akuntansi antara kelompok siswa yang belajar dengan menggunakan model pembelajaran quantum teaching berbantuan media audiovisual dan kelompok siswa yang belajar tidak dengan menggunakan model pembelajaran quantum teaching berbantuan media audiovisual, terdapat perbedaan hasil belajar dasar-dasar akuntansi antara kelompok siswa yang belajar dengan menggunakan model pembelajaran quantum teaching berbantuan media audiovisual dan kelompok siswa yang belajar tidak dengan menggunakan model pembelajaran quantum teaching berbantuan media audiovisual.

Hasil penelitian ini sejalan dengan pendapat Ruseffendi (dalam Susanto, 2013) yang menyatakan, faktor-faktor yang mempengaruhi hasil belajar meliputi kecerdasan, kesiapan anak, bakat anak, kemauan belajar, minat anak, model penyajian materi, pribadi dan sikap guru, suasana belajar, kompetensi guru, dan kondisi masyarakat. Pada saat siswa merasa pelaksanaan pembelajaran yang dilakukan mononton maka siswa akan merasa bosan dan tidak menghiraukan materi yang dijelaskan oleh guru. Begitu juga sebaliknya ketika siswa merasa bahwa model pembelajaran yang digunakan menarik maka siswa akan memperhatikan materi yang akan dijelaskan oleh guru. Sehingga hasil belajar siswa akan optimal. Salah satu model pembelajaran yang menarik adalah model pembelajaran quantum teaching, ini dilihat dari interaksi diantara siswa dengan siswa serta siswa dengan guru ketika proses berdiskusi berlangsung. Pendapat tersebut sesuai dengan pendapat Deporter, dkk (2010) yang menyatakan, quantum teaching adalah pengubahan bermacam-macam interaksi yang ada didalam dan disekitar momen belajar. Interaksi-interaksi tersebut mencakup unsur-unsur untuk belajar efektif yang mempengaruhi kesuksesan siswa. Pendapat tersebut, didukung oleh penelitian yang dilakukan oleh Firdansyah (2014) yang menyatakan bahwa, hasil belajar siswa yang menggunakan model pembelajaran quantum teaching lebih baik, dari pada hasil belajar siswa yang tidak 
menggunakan model pembelajaran quantum teaching.

Selain itu adanya langkah pembelajaran TANDUR dapat menumbuhkan keinginan tahunan siswa sehingga membuat siswa tertarik akan materi yang diajarkan dan memberikan kesempatan kepada siswa untuk berinteraksi langsung dalam lingkungan belajar sehingga siswa akan lebih memahami pembelajaran yang dilaksanakan. Interaksi yang dilakukan oleh siswa berkaitan dengan kegiatan berdiskusi. Kegiatan diskusi dapat meningkatkan keterampilan peserta didik dalam memecahkan suatu masalah. Memecahkan suatu permasalahan memberikan kesempatan pada siswa untuk mengeluarkan kemampuannya dan membantu siswa terlatih berpatisipasi dalam kelompok secara demokratis.

$$
\text { Kegiatan diskusi akan }
$$

meningkatkan motivasi belajar siswa karena siswa diberikan kesempatan untuk mempresentasikan hasil kerjanya. Selain hal tersebut, motivasi belajar siswa terlihat dari antusias siswa ketika diberikan kesempatan untuk menjawab suatu pertanyaan. Siswa yang berani mempresentasikan hasil kerjanya dan dapat menjawab suatu pertanyaan yang diajukan akan diberikan suatu penghargaan berupa tepuk tangan, pujian, hadiah, atau reward yang dapat memperkuat suatu respon tertentu.

Pemberian

penghargaan

memberikan kesan pada siswa bahwa usaha yang mereka laksanakan selama pembelajaran patut dihargai dan dirayakan. Pemberian penghargaan dikelas menjadikan siswa lebih bersemangat untuk berhasil dalam pembelajaran sehingga siswa termotivasi dalam belajar. Dengan demikian, dapat dikatakan bahwa penghargaan dapat meningkatkan motivasi belajar siswa, yang berpengaruh pula pada keberhasilan hasil belajar siswa. Pendapat ini sesuai dengan pendapat Deporter, dkk (2010) yang menyatakan, sesuatu yang layak dipelajari maka layak pula dirayakan. Pendapat tersebut, didukung oleh penelitian yang dilakukan oleh Natalia (2014) yang menyatakan bahwa, pemberian penghargaan di kelas menjadikan siswa lebih bersemangat untuk berhasil dalam pembelajaran dan menjadikan siswa lebih fokus ketika guru menjelaskan. Dengan demikian, motivasi dan hasil belajar siswa menjadi meningkat.

Adanya media audiovisual yang diterapkan menjadikan pembelajaran semakin menyenangkan, yang mengakibatkan motivasi belajar siswa semakin meningkat. Hal tersebut terlihat ketika siswa serius dalam memperhatikan audiovisual yang ditampilkan sehingga membantu siswa lebih memahami materi yang dipelajari. Media audiovisual juga dapat menghidupkan suasana belajar di dalam kelas sehingga siswa menjadi tidak bosan dan jenuh dalam mengikuti pembelajaran yang berlangsung, karena media audiovisual mengandung unsur gambar dan suara yang bisa dilihat dan didengar yang membuat pembelajaran semakin menarik.

Pendapat tersebut sesuai dengan pendapat Sanjaya (2008) yang menyatakan, penggunaan media audiovisual dapat menambah motivasi belajar siswa sehingga perhatian siswa terhadap materi pembelajaran dapat lebih meningkat.

Pendapat tersebut, didukung oleh penelitian yang dilakukan oleh Purwono (2014) yang menyatakan bahwa, pelaksanaan penggunaan media audiovisual dalam pembelajaran memberikan dampak positif bagi siswa. Siswa mendapatkan suasana pembelajaran yang baru, suasana kelas menjadi lebih interaktif, pembelajaran mejadi menarik, siswa menjadi antusias dan lebih termotivasi untuk mengikuti pembelajaran.

Meskipun ada perbedaan motivasi dan hasil belajar dengan menggunakan model pembelajaran quantum teaching berbantuan media audiovisual, tetapi dari hasil penelitian yang telah dilakukan ada beberapa kendala yang ditemukan, yaitu ada beberapa siswa yang kurang siap belajar menggunakan model pembelajaran quantum teaching berbantuan media audiovisual. Hal tersebut dikarenakan selama ini siswa terbiasa belajar dengan hanya menerima materi pelajaran dari guru 
tanpa berusaha mencarinya. Selain itu model pembelajaran quantum teaching juga menyita waktu yang cukup lama sehingga waktu proses belajar mengajar menjadi kurang dan mengakibatkan materi pelajaran dilanjutkan pada pertemuan berikutnya.

\section{SIMPULAN DAN SARAN Simpulan}

Berdasarkan hasil penelitian dan pembahasan yang telah dilakukan maka dapat ditarik simpulan sebagai berikut. Terdapat perbedaan motivasi dan hasil belajar dasar-dasar akuntansi antara kelompok siswa yang belajar dengan menggunakan model pembelajaran quantum teaching berbantuan media audiovisual dan kelompok siswa yang belajar tidak dengan menggunakan model pembelajaran quantum teaching berbantuan media audiovisual pada siswa kelas X Akuntansi di SMK N 1 Singaraja tahun ajaran 2017/2018. Hal ini ditunjukkan dengan harga $\mathrm{F}$ untuk Pillai's Trace, Wilk's Lambda, Hotteling's Trace, Ray's Largest Root memiliki $F_{\text {hitung }}$ adalah 15,241 dan memiliki signifikansi sebesar 0,000 0,05.

$$
\text { Terdapat perbedaan motivasi }
$$

belajar dasar-dasar akuntansi antara kelompok siswa yang belajar dengan menggunakan model pembelajaran quantum teaching berbantuan media audiovisual dan kelompok siswa yang belajar tidak dengan menggunakan model pembelajaran quantum teaching berbantuan media audiovisual pada siswa kelas X Akuntansi di SMK N 1 Singaraja tahun ajaran 2017/2018. Hal ini ditunjukkan dengan nilai $F_{\text {hitung }}$ adalah 6,552 dan nilai signifikansi sebesar 0,013<0,05.

Terdapat perbedaan hasil belajar dasar-dasar akuntansi antara kelompok siswa yang belajar dengan menggunakan model pembelajaran quantum teaching berbantuan media audiovisual dan kelompok siswa yang belajar tidak dengan menggunakan model pembelajaran quantum teaching berbanatuan media audiovisual pada siswa kelas $X$ Akuntansi di SMK N 1 Singaraja tahun ajaran 2017/2018. Hal ini ditunjukkan dengan nilai $F_{\text {hitung }}$ adalah 24,099 dan nilai signifikansi sebesar $0,000<0,05$.

\section{Saran}

$\begin{array}{ccc}\text { Saran yang } & \text { disampaikan } \\ \text { berdasarkan penelitian yang telah }\end{array}$ dilakukan di kelas X Akuntansi di SMK Negeri 1 Singaraja, adalah sebagai berikut.

Saran pertama untuk guru, yaitu dari hasil penelitian yang telah peneliti lakukan dengan menggunakan model pembelajaran quantum teaching berbantuan media audiovisual terdapat dampak positif yang didapatkan selama proses pembelajaran berlangsung, alangkah baiknya jika model pembelajaran ini bisa diterapkan oleh guru dalam proses pembelajaran di dalam kelas untuk memperkaya model pembelajaran yang dapat membuat siswa tidak mudah jenuh dalam proses pembelajaran, pembelajaran menjadi lebih menyenangkan, dan siswa menjadi lebih aktif dalam belajar.

Selain itu, peneliti mengharapkan untuk bisa menerapkan model pembelajaran lainnya yang menarik dan bervariasi sesuai dengan materi pelajaran dan karakteristik siswa dalam rangka meningkatkan motivasi dan hasil belajar siswa, dan alangkah baiknya jika guru membawa suasana

belajar ke alam lingkungan siswa dan mengambil contoh-contoh masalah yang ada disekitar siswa.

Saran kedua untuk siswa, yaitu sebaiknya siswa lebih proaktif mencari sumber belajar lain sebagai tambahan referensi dalam pembelajaran tanpa menunggu perintah dari guru, karena pelajaran akuntansi adalah pelajaran yang sangat penting untuk semua bidang pekerjaan dan kehidupan sehingga perlu dipelajari.

\section{DAFT AR PUST AKA}

Agung, A.A Gede. 2014. Buku Ajar Metodologi Penelitian Pendidikan, edisi 2. Cetakan Pertama. Singaraja: Aditya Media Publishing.

Arsyad, Azhar. 2013. Media Pembelajaran. Jakarta: PT Raja Grafindo Persada.

Candiasa. 2011. Statistik Univariant Dan Bivariant Disertai Aplikasi SPSS Singaraja: Universitas Pendidikan Ganesha. 
Deporter, Bobbi, dkk. 2010. Quantum Teaching Mempraktikkan Quantum Learning di Ruang-Ruang Kelas. Bandung: Kaifa.

Djamarah, S. B. \& Aswan Zain. 2006. Strategi Belajar Mengajar. Jakarta: PT Rineka Cipta.

Firdansyah, Aggih. 2014. Pengaruh Model Pembelajaran Quantum Teaching Terhadap Hasil Belajar Siswa dalam Mata Pelajaran Akuntansi Di Kelas X1 Farmasi SMK PGRI 2 Cimahi. Abstrak. Universitas Pendidikan Indonesia.

Koyan, I Wayan. 2011. Asesmen dalam Pendidikan. Singaraja: Universitas Pendidikan Ganesha Press.

Natalia. 2014. Pengaruh Pemberian Penghargaan Oleh Guru Ekonomi Terhadap Motivasi Belajar Siswa Kelas X MAN 2 Pontianak. Jurnal Pendidikan dan Pembelajaran, Volume 3 (No 6): hal 9.

Purwono, Joni. 2014. Penggunaan Media Audio-Visual Pada Mata Pelajaran IImu Pengetahuan Alam Di Sekolah Menengah Pertama Negeri 1 Pacitan. Jurnal Teknologi Pendidikan dan Pembelajaran, Volume 2 (No 2): hal 141.

Rusman. 2015. Pembelajaran Tematik Terpadu: Teori Praktik dan Penilaian. Jakarta: PT Raja Grafindo Persada.

Sanjaya, Wina. 2008. Strategi Pembelajaran Berorientasi Standar Proses Pendidikan, edisi pertama. Cetakan ke lima. Jakarta: Kencana.

Sadiman, Arif S., dkk. 2006. Media Pendidikan Pengertian Pengembangan dan Pemanfaatnya. Jakarta: PT Raja Grafindo Persada.

Sardiman. 2005. Interaksi dan Motivasi Belajar Mengajar. Jakarta: PT Raja Grafindo Persada.

Sobandi, Bandi. 2008. Model Pembelajaran Kritik dan Apresiasi Seni Rupa. Bandung: Direktorat Jendral Pendidikan Tinggi.
Susanto, Ahmad. 2013. Teori Belajar dan Pembelajaran Di Sekolah Dasar. Jakarta: Prenadamedia Group.

Suwatra, dkk. 2015. Belajar dan Pembelajaran Sekolah Dasar. Singaraja: Undiksha.

Trianto. 2007. Model-Model Pembelajaran Inovatif Berorientasi Konstruktivistik. Cetakan pertama. Jakarta: Prestasi Pustaka.

Uno, B. Hamzah. 2008. Teori Motivasi dan Pengukurannya, edisi pertama. Cetakan ketiga. Jakarta: Bumi Aksara. 